\title{
Cold Outbreaks at the Mesoscale in the Western Mediterranean Basin: From Raincells to Rainbands
}

\author{
Jordi Mazon ${ }^{1}$ and David Pino ${ }^{1,2}$ \\ ${ }^{1}$ Department of Physics, Universitat Politècnica de Catalunya-BarcelonaTech, Esteve Terrades 5, Building C3, Office 105, Castelldefels, \\ 08860 Barcelona, Spain \\ ${ }^{2}$ Institute for Space Studies of Catalonia, Barcelona, Spain
}

Correspondence should be addressed to Jordi Mazon; jordi.mazon@upc.edu

Received 24 January 2017; Revised 15 March 2017; Accepted 4 April 2017; Published 16 May 2017

Academic Editor: George Kallos

Copyright (c) 2017 Jordi Mazon and David Pino. This is an open access article distributed under the Creative Commons Attribution License, which permits unrestricted use, distribution, and reproduction in any medium, provided the original work is properly cited.

\begin{abstract}
This paper investigates cold outbreaks that form offshore density currents within the whole mesoscale over the Western Mediterranean basin. Reflectivity radar and satellite images are used to detect clouds and precipitation that are associated with these density currents in the meso- $\alpha$, meso- $\beta$, and meso- $\gamma$ over the Western Mediterranean basin (WMB). Version 3.3 of the WRF-ARW model is used to describe the formation and evolution of these density currents and to estimate their lifetime as well as horizontal and vertical scales. Based on the observations and simulations, this paper suggests that a new perspective could effectively be adopted regarding the WMB region delineated by the Balearic Islands, the northeastern Iberian Peninsula, and the Gulf of Lion, where inland cold outbreaks develop into density currents that move offshore and can produce precipitation ranging from raincells to rainbands at the whole mesoscale.
\end{abstract}

\section{Introduction}

Offshore precipitation induced by cold outbreaks has been studied by several authors, mainly for tropical regions [16]. These authors explain the occurrence of precipitation as follows. From late afternoon and throughout the night, inland air cools faster than air at the coastline and over the sea. Consequently, this cooler and denser air begins to drain towards the coast by descending from mountain ranges and following rivers and dry streams until it forms a density current driven by drainage winds. A density current is the intrusion of a denser fluid beneath a lighter one, due mainly to the hydrostatic forces arising from gravity and the density differences [7]. These density currents usually form a coastal front when interacting with the warmer sea air, thus leading to areas of cloud and rain over the sea [8-10].

The theory of density currents was developed by Benjamin [11], based on previous studies [12-15]. He found that the speed of a density current depends on the depth of the cold air mass and on the potential temperature of the warm and cold air masses. The theoretical predictions were confirmed by laboratory experiments on density currents in the late 1970s by Simpson and Britter in his iconic paper [16].

Figure 1 shows a schematic representation of a density current moving over the sea.

Once the density current moves offshore, the wind speeds of the warm $\left(V_{w}\right)$ and cold $\left(V_{c}\right)$ air masses (with potential temperatures $\theta_{w}$ and $\theta_{c}$, resp.) influence the intensity and position of the possible precipitation. Several authors $[8,17]$ showed that the position and rate of the precipitation are determined by the intensity of the prevailing wind blowing towards the coast and the land-sea temperature difference. Specifically, $V_{c}$ increases with the potential temperature difference between the cold and warm air masses. Consequently, if a large landsea temperature difference exists, the precipitation moves offshore, whereas large values of $V_{w}$ move it onshore [4]. As expected, $V_{c}$ is also influenced by roughness length over land [18].

At the convergence zone between the two air masses, the moisture in the ascending warm air condenses and forms stratiform clouds if the air reaches the Lifting Condensation Level (LCL). In some cases, convective clouds appear if the 


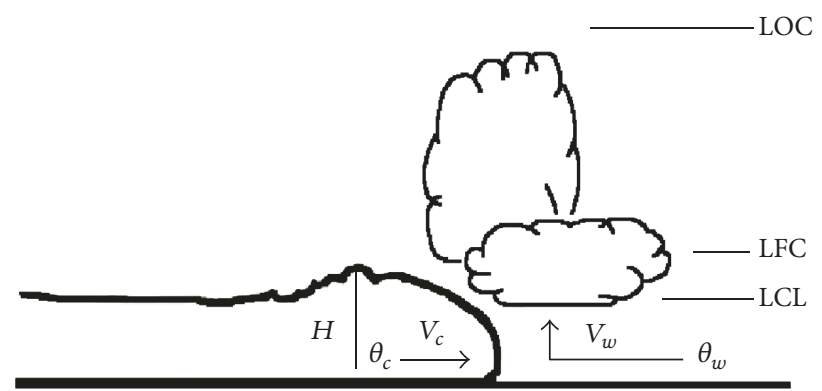

FIGURE 1: Scheme of a density current interacting with a warmer air mass. See the text for an explanation of each variable.

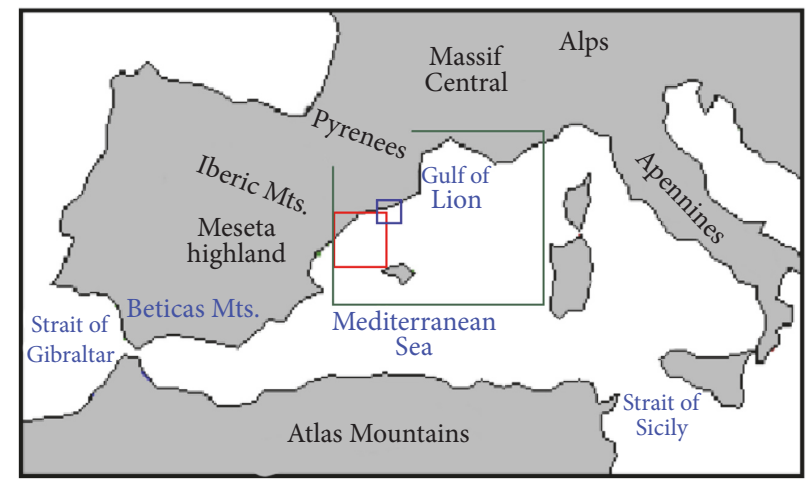

FIGURE 2: Schematic representation of the WMB with the locations of the main orographic features. Squares indicate the areas where offshore density currents were detected at the meso- $\alpha$ (green square), meso- $\beta$ (red square), and meso- $\gamma$ (blue square) scales.

corresponding Level of Free Convection (LFC) is reached. In both cases, the depth of the colder inland air mass $(H)$ plays an important role in helping the wetter and warmer maritime air mass reach LCL or LFC $[8,19]$. No clouds will form if $H<$ LCL.

1.1. Density Currents over the Mediterranean Basin. There are only a few studies focusing on density currents that induce coastal fronts in the Mediterranean basin. Neumann [9] proposed using the interaction between a prevailing synoptic wind and a land breeze to explain the observed offshore convection in the South of Israel. Goldreich et al. [20] described local nocturnal precipitation from November to September that was produced by coastal fronts near the coastline in the South of Israel, which were formed by a land breeze interacting with a synoptic flow. This precipitation represented a significant contribution to the total amount of the area's rainfall during the dry years. Also, in this area, [17] suggested that the concave shape of the coastline plays an important role in enhancing the convergence of the land breeze and synoptic winds near the coastline. In the Western Mediterranean basin, [21] detected nocturnal convection at the mouths of three rivers that flow into the northeastern coast of the Iberian Peninsula. These authors qualitatively described this type of precipitation and argued that it was formed by nocturnal surface convergence associated with density currents forming a coastal front.
1.2. The Western Mediterranean Basin. The Western Mediterranean basin (hereafter WMB) is a semienclosed basin due to the many surrounding mountain ranges, which exceed $2000 \mathrm{~m}$ in many areas (see Figure 2). To the north, there are three major mountain ranges (Pyrenees, Massif Central, and Alps). These topographical features combine to create a channeling effect of the air that flows between these mountain ranges. Moreover, along the southern coast of the WMB, the Atlas mountain range dominates North Africa, with elevations that reach $2000 \mathrm{~m}$ close to the coastline. In the western part, some mountain ranges in the Iberian Peninsula (Betica Mountains, Iberic System) are located close to the coast, with elevations of between 700 and $3000 \mathrm{~m}$. Finally, in the eastern part of the area, the Apennines range encloses the basin. Consequently, the high insolation causes the maritime air mass to have particular characteristics that are similar to a maritime tropical air mass [22], which can be replaced only by three main points: the Gulf of Lion, and the straits of Sicilia, and Gibraltar. In this scenario, cold outbreaks occurring over this warm and moist maritime air mass may induce the formation of coastal density currents across all of the mesoscales in the WMB [23].

The complex topography around the WMB plays an important role in two aspects. First, it channels northern flows from the Massif Central in France and encourages drainage winds to follow the valleys and slopes of some mountains near the coast. Second, it encloses the basin and consequently makes the WMB the source region of maritime 


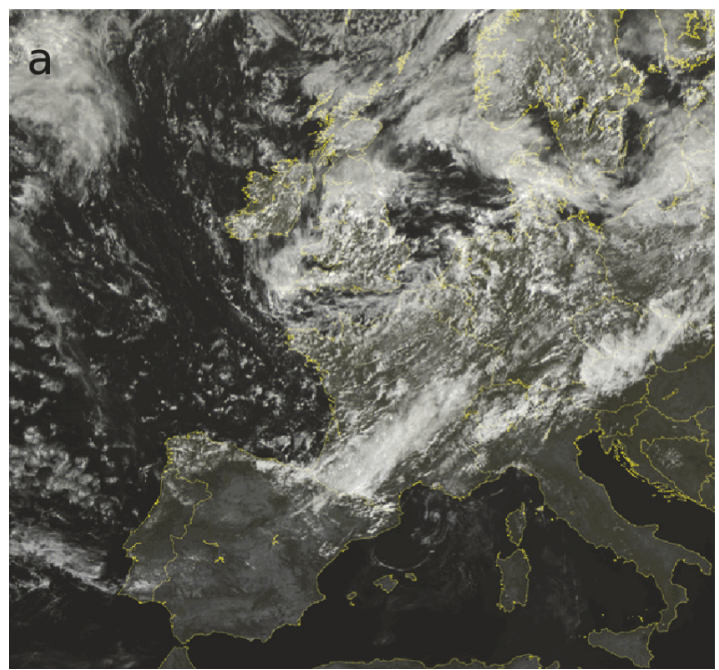

(a)

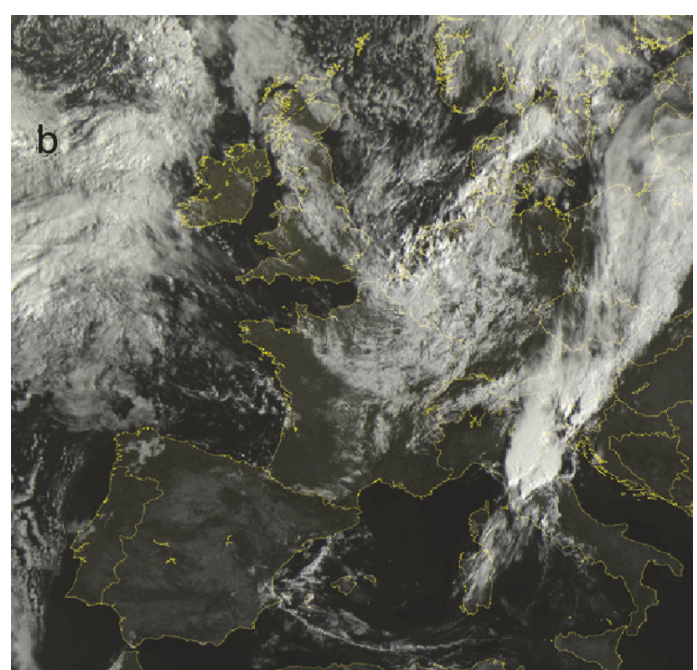

(b)

FIgURE 3: Visible Meteosat satellite image on (a) 25 August 2012 at 11:00 UTC and (b) 26 August 2012 at 08:00 UTC.

Mediterranean air, which is a relatively warm and wet air mass that produces an intense air-sea heat exchange [24]. These surface fluxes of moisture and heat from the sea-water provide the sea air with humidity and heat, which in turn enhance convection, cloud formation, and sea surface cooling [25]. Associated with density currents and this exchange of heat, shallow and even convective clouds can form with the possibility of weak precipitation [26].

Cold air entering into the WMB at the meso- $\alpha$ (500-2000 km, 1-2 days) usually comes from the Gulf of Lion and is associated with a synoptic northwesterly flow known as the Mistral or tramontana wind. The Mistral is a cold and strong northwesterly to north-northeasterly offshore wind that runs perpendicular to the coast of the Gulf of Lion. Its influence occasionally extends beyond the Gulf of Lion [27] and, being one of the primary causes of storms over some areas of the WMB, it affects the weather across the whole basin [28, 29].

Additionally, at the scales of meso- $\beta(50-500 \mathrm{~km}, 12-24$ hours) and meso- $\gamma$ (5-50 km, 0.5-12 hours), cold outbreaks in the $\mathrm{WMB}$ are usually associated with drainage flows that occur at nighttime [30-33]. If the maritime air mass is warm enough, these nocturnal flows driving the inland cold air offshore can form meso- $\beta$ or meso- $\gamma$ density currents over the warmer and wetter Mediterranean Sea air mass.

This paper draws on Meteosat satellite observations, images from the radar networks of either the Spanish Meteorological Agency or the Catalan Weather Service, and numerical simulations run on version 3.3 of the WRF-ARW model [34]. The objective here is to show three samples of episodes of cold outbreaks over the relatively warm and wet maritime sea air, all of which occurred in the WMB at the meso- $\alpha$, meso- $\beta$, and meso- $\gamma$ scales. From the simulation results, we estimate the values of the temporal, horizontal, and vertical scales, which thus allow us to contribute a new point of view and improve knowledge of the atmospheric dynamics in the WMB.

The paper is structured as follows: observations of precipitation and cloudiness associated with density currents in the WMB are shown in Section 2. Section 3 focuses on the WRF set-up. Section 4 shows the simulation of the density currents formed at the meso- $\alpha$, meso- $\beta$, and meso- $\gamma$ scales. General results and main conclusions are provided in Section 5.

\section{Observations}

Based on the available data, three episodes of cold outbreaks in the Western Mediterranean basin have been selected. Meso- $\beta$ and meso- $\gamma$ episodes are associated with offshore nocturnal precipitation near the coastline. Radar images from the Catalan Meteorological Service and the Spanish Meteorological Agency were used to detect these episodes. The meso- $\alpha$ episode is associated with an arc of clouds spreading out thought the Gulf of Lion. Meteosat data is used for detecting the cloudiness associated with this episode.

Cloudiness associated with the meso- $\alpha$ density current occurred on 25-26 August 2012 and was recorded by Meteosat satellite. Figure 3 shows the Meteosat image on (a) 25 August at 11:00 UTC and (b) on 26 August 2012 at 08:00 UTC. An arc of clouds is observed near the Gulf of Lion at 11:00 UTC on 25 August (Figure 3(a)) moving offshore and reaching the North African coast at 08:00 on 26 August 2012 (Figure 3(b)). This cloud arc lasted around 26 hours and its final extension is around $1500 \mathrm{~km}$.

Precipitation associated with the meso- $\beta$ density current occurred during the night of 6 September 2011 and was recorded by the radar network of the Spanish Meteorological Agency (AEMET). A rainband was recorded at the northeast of the Iberian Peninsula from 22:00 UTC on 5 September 2011 until early morning on 6 September 2011. Figure 4 


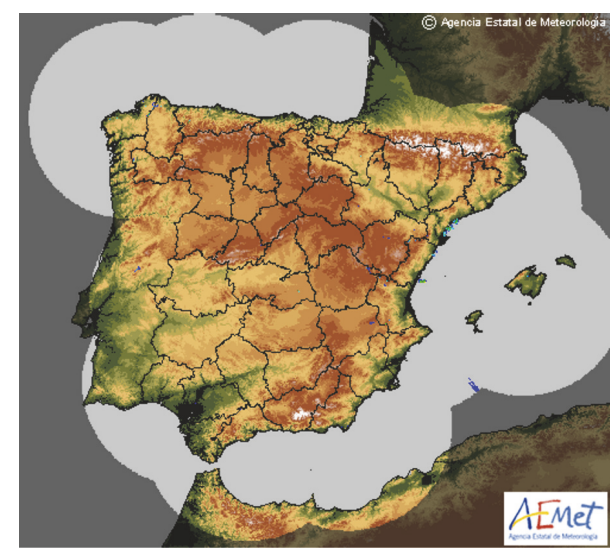

Reflectivity (dbz)

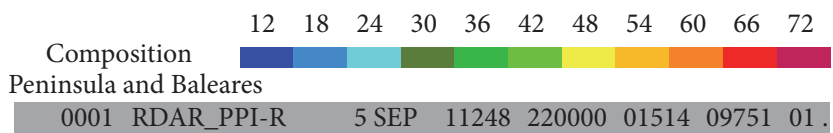

(a)

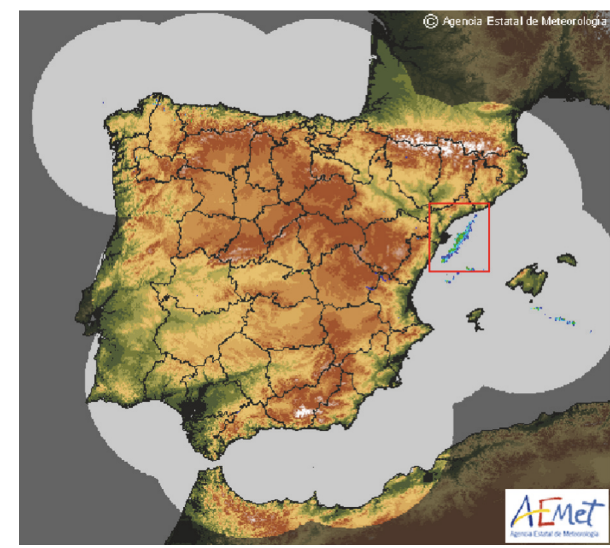

Reflectivity (dbz)

$\begin{array}{lllllllllll}12 & 18 & 24 & 30 & 36 & 42 & 48 & 54 & 60 & 66 & 72\end{array}$

Composition
Peninsula and Baleares 0001 RDAR_PPI-R $\begin{array}{llllll}6 \text { SEP } & 11249 & 030000 & 0151409751 & 01 .\end{array}$

(c)

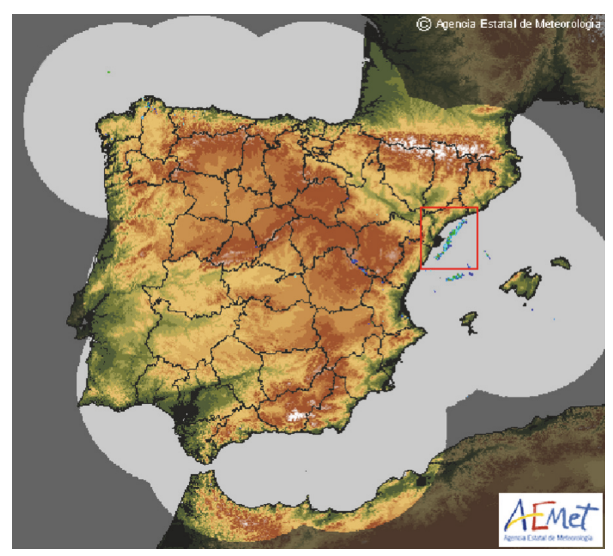

Reflectivity (dbz)

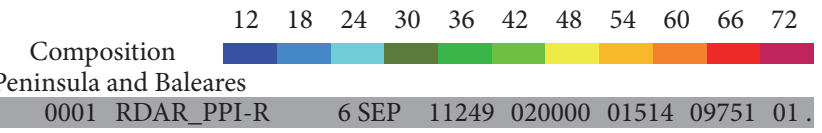

(b)

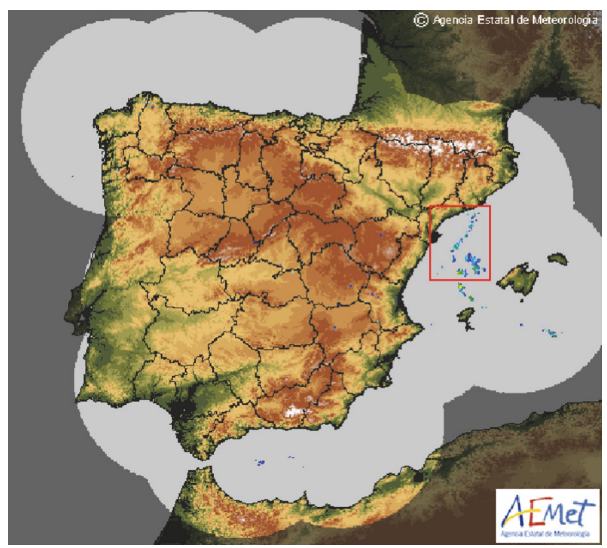

Reflectivity (dbz)

$\begin{array}{lllllllllll}12 & 18 & 24 & 30 & 36 & 42 & 48 & 54 & 60 & 66 & 72\end{array}$ Composition
Peninsula and Baleares 0001 RDAR_PPI-R 6SEP 11249070000015140975101.

(d)

FIGURE 4: Reflectivity radar images at (a) 22:00 UTC on 5 September 2011 and (b) 01:00 UTC and (c) 03:00 UTC and (d) 08:00 on 6 September 2011. Source: Spanish Meteorological Agency.

shows the radar image at (a) 22:00 UTC on 5 September 2011 and (b) 01:00 and (c) 03:00 and (d) 08:00 UTC on 6 September 2011. From the analysis of the rainband recorded by the reflectivity radar images, the estimated lifetime was around $10 \mathrm{~h}$, with a maximum extension of around $200 \mathrm{~km}$.

Figure 5 shows the radar images from the Catalan Meteorological Service at 21:30 and 22:00 on 13 October 2010. Three rainfall areas formed at the mouths of three rivers located on the northeast coast of the Iberian Peninsula: Llobregat, Besos, and Tordera (indicated, resp., as L, B, and T in Figure 4(a)). The precipitation started at 21:00 UTC, forming an offshore rainband with a maximum length of around $30 \mathrm{~km}$. At 00:00 UTC the precipitation vanished.

\section{WRF Set-Up}

Version 3.3 of the WRF-ARW model is used to simulate the three offshore cloud bands and rainbands. For all the simulations, $42 \eta$-vertical levels have been defined with 23 of the levels below $1 \mathrm{~km}$. Regarding the physical parameterizations, the MRF [35] scheme is used for the PBL; RRTM for long-wave radiation [36]; the MM5 shortwave scheme for shortwave radiation [37]; and the WSM 6-class scheme [38] for the microphysics parameterization. No cumulus parameterization is used for any of the smallest domains because their horizontal resolution is lower than $3 \mathrm{~km}$ in all the simulations. The initial and boundary conditions were updated every six hours with information obtained from 

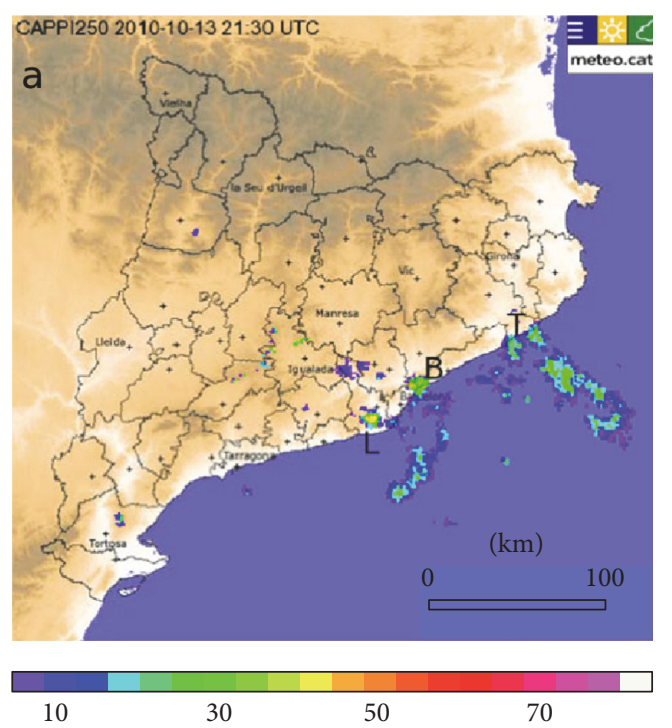

30
50 (dbz)

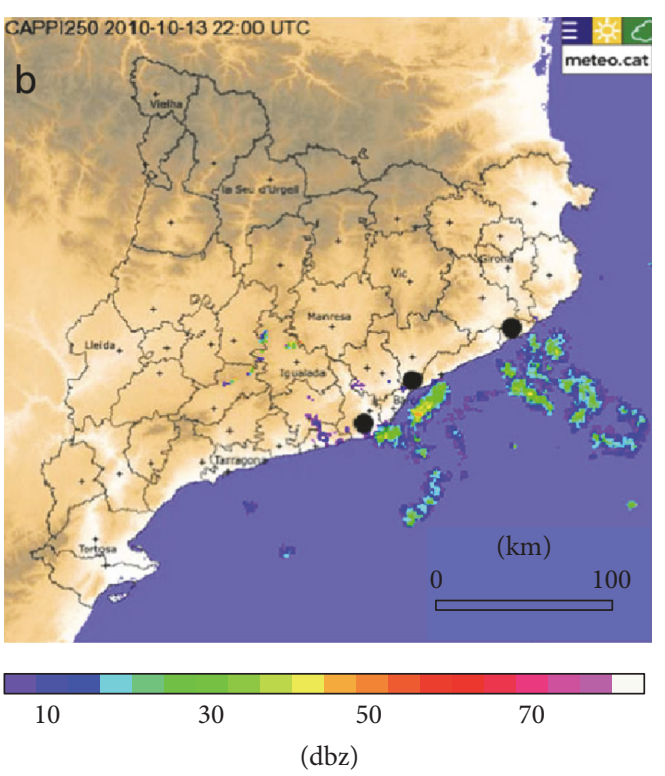

(b)

(a)

70

(1)

FIGURE 5: Reflectivity radar images at (a) 21:30 UTC and (b) 22:00 UTC on 13 October 2010. The black dots in (b) indicate the mouth of the rivers Llobregat, Besos, and Tordera (L, B, and T in (a)). Source: Catalan Meteorological Service.

the analysis of the ECMWF model at $0.125^{\circ}$ of horizontal resolution. In all the simulations performed, two-way nested domains have been used.

For the event that occurred on 25 August 2012 in the meso- $\alpha$, two nested domains with 3 and $1 \mathrm{~km}$ of horizontal resolution are defined (see Figure 6(a)). The simulation begins on 24 August 2012 at 00:00 UTC and runs for 72 hours. For the event that occurred on 6 September 2011 in the meso- $\beta$ scale, three nested domains have been defined with 18,6 , and $2 \mathrm{~km}$ of horizontal resolution (see Figure $6(\mathrm{~b})$ ). The simulation starts on 4 September 2011 at 00:00 UTC and runs for 72 hours. For the event that occurred on 11 October 2010 in the meso- $\gamma$ scale, four nested domains have been defined with $27,9,3$, and $1 \mathrm{~km}$ of horizontal resolution (see Figure 6(c)). The simulation starts on 10 October 2010 at 00:00 UTC and runs for 94 hours.

\section{Simulation Results}

The length $(L)$, lifetime $(T)$, and depth of the cold air mass $(H)$ associated with each density current are estimated from the simulations. The length $(L)$ and lifetime $(T)$ are estimated by analyzing the horizontal fields of convergence, the wind field, and cloud mixing-ratio. The depth of the cold air mass $(H)$ is estimated from the vertical cross-sections of the potential temperature along the lines shown in Figure 6. $H$ is defined as the maximum height where a horizontal gradient of potential temperature exists [30].

4.1. The Meso- $\alpha$ Density Current on 25 August 2012. Figure 7 shows the surface wind field (arrows) and the liquid water mixing-ratio (color contours) at $700 \mathrm{~m}$ in domain 1 at (a) 08:00, (b) 10:00, and (c) 20:00 UTC on 25 and (d) 08:00
UTC on 26 August 2012. We use this height because it is the minimum height where cloudiness appears and clearly forms an arc.

During the night and early morning of 25 August 2012, southerly winds prevailed over the Gulf of Lion (not shown). At 08:00 UTC (Figure 7(a)), a northwesterly flow prevails. A low cloud area with an arc shape driven by northwesterly flow is simulated at 10:00 UTC (Figure 7(b)). This cloud arc expands out to the south of the WMB, driven by the northwesterly flow. A well-defined cloud arc is simulated at 20:00 UTC on 25 August 2012 (Figure 7(c)). The northwesterly Mistral flow reaches $17.5 \mathrm{~m} \mathrm{~s}^{-1}$ over the Gulf of Lion. At 08:00 UTC on 26 August 2012 (Figure 7(d)), the cloud arc is located near the north coast of Africa at approximately the same location that was observed by the Meteosat satellite (see Figure 3(a)), with a length of around $1500 \mathrm{~km}$. From this moment, the simulated cloud arc starts to disappear.

Figure 8 shows the simulated potential temperature (color contours), wind field (arrows), and liquid water mixing-ratio (black contour lines) at 20:00 UTC on 25 August 2012 in the vertical cross section along lines (a) A1-A2 and (b) B1B2 indicated in Figure 6(a). Following the definition and methodology for estimating $H$ proposed by Mazon and Pino [32], the estimated depth of the cold air mass is around $700-1000 \mathrm{~m}$ in both Figures 8(a) and 8(b). Approximately over the head of this density current, WRF simulates the liquid water mixing-ratio extending vertically from around $700 \mathrm{~m}$ up to $1500 \mathrm{~m}$.

4.2. The Meso- $\beta$ Scale Density Current on 6 September 2011. Figure 9 shows the surface convergence field at 00:00, 03:00, and 08:00 UTC on 6 September 2011. These areas of convergence are formed by the inland cold air mass driven 


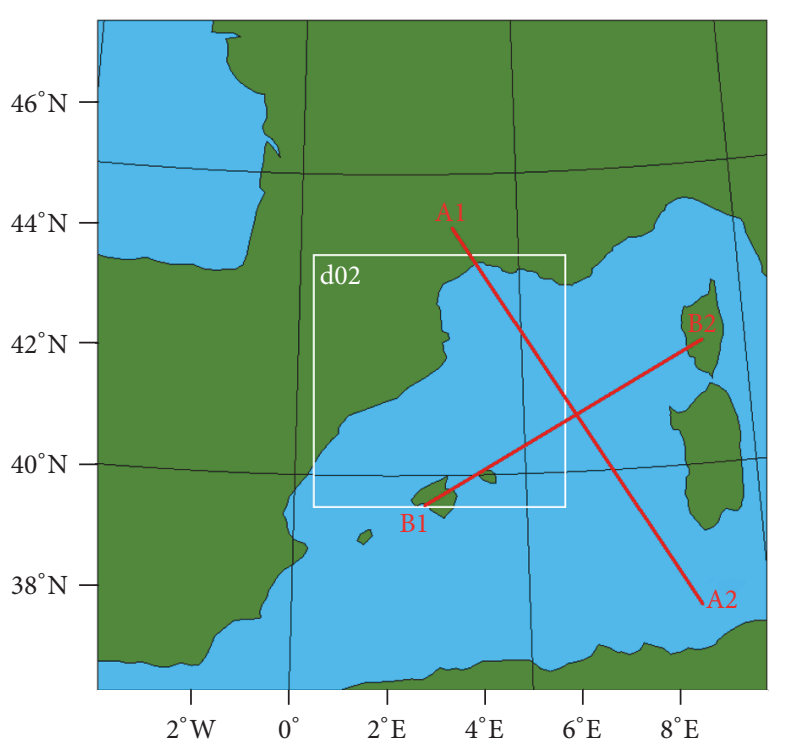

(a)

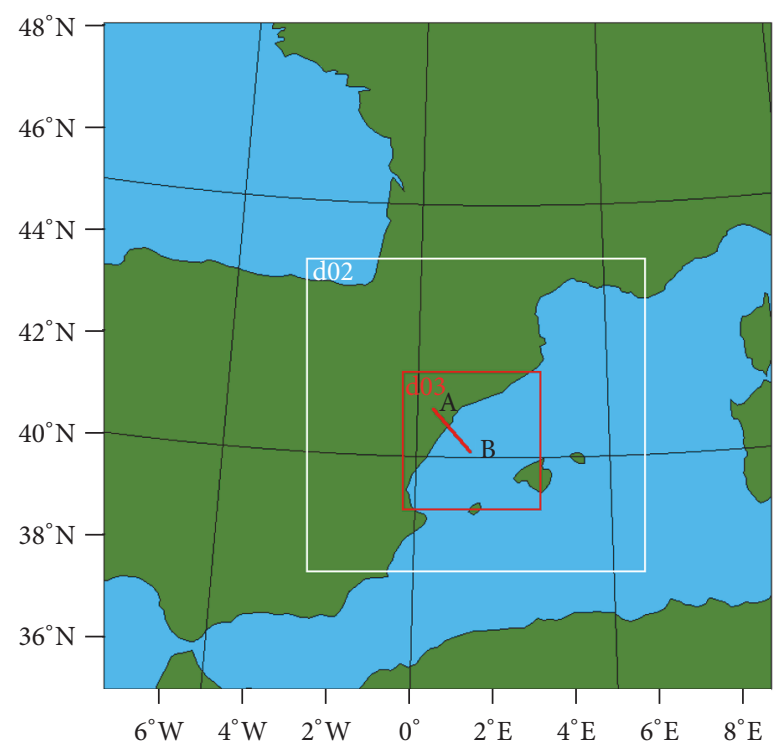

(b)

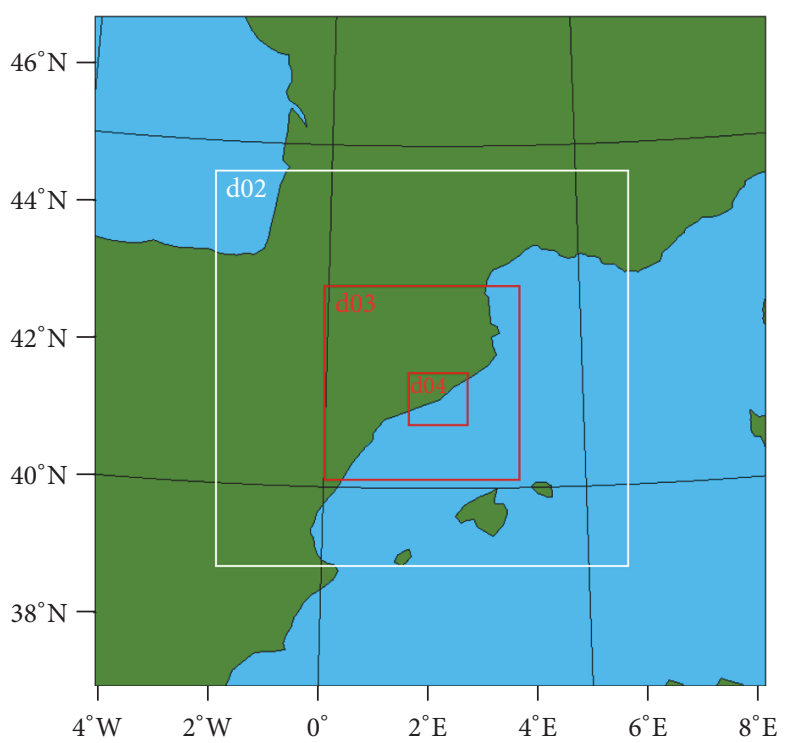

(c)

Figure 6: WRF-domains used for each episode. For the meso- $\alpha$ density current on 25 August 2012 (a), the largest domain is used for analyzing this event. Lines A1-A2 and B1-B2 are the projection of the vertical cross section used in the analysis of this event. In (b), domain 3 (d03, red square) is used to study the meso- $\beta$ scale density current on 6 September 2011. Line A-B indicates the projection of the vertical cross section. In (c), the small red square (d04) is used for the meso- $\gamma$ density current on 11 October 2010.

by drainage winds interacting with the warmer maritime air mass driven by the prevailing easterly flow. The maximum length of this line of convergence reaches around $150 \mathrm{~km}$ and occurs between 03:00 and 08:00. This line of convergence vanishes at 08:00 UTC.

Around this simulated line convergence, a line of precipitation is also simulated according to the reflectivity radar images from the Spanish Meteorological Agency shown in Figure 4. Figure 10 shows the 1-h accumulated precipitation (color contours) and the surface wind field (arrows) at (a) 22:00 on 5 September 2011 and (b) 03:00 UTC and (c) 06:00 and (d) 08:00 on 6 September 2011. At 22:00 UTC on 5 September 2011 (Figure 10(a)), a precipitation cell is simulated over the coastline. At 00:00 UTC on 6 September 2011, some precipitation cells are simulated offshore, driven by drainage winds. An offshore rainband with approximately $150 \mathrm{~km}$ length formed by several raincells is simulated at 03:00 and 08:00 UTC (Figures 10(c) and 10(d), resp.). At 09:00 UTC the rainband vanishes (not shown).

Figure 11 shows the vertical cross section along line AB shown in Figure 6(b) of the potential temperature (color contours), wind field (arrows), and liquid water mixingratio (black contour lines) at (a) 00:00 UTC, (b) 02:00 UTC, (c) 04:00 UTC, and (d) 06:00 UTC on 6 September 


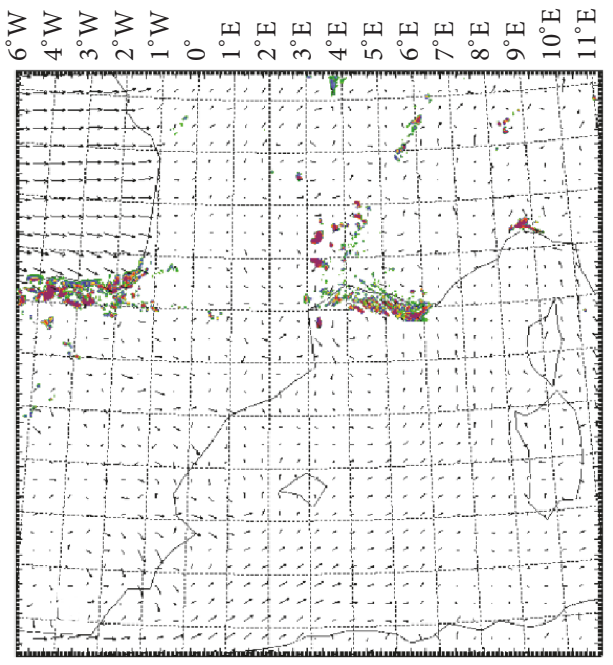

(a)

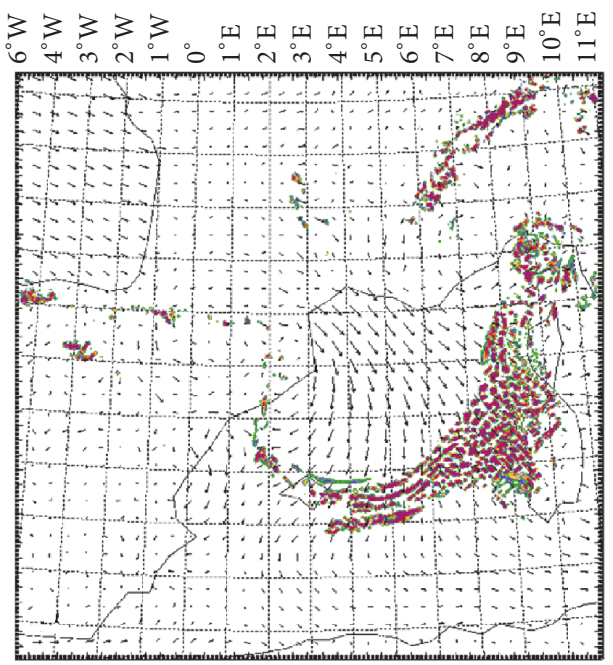

(c)

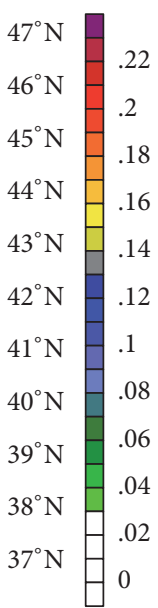

.22
.2
.18
.16
.14
.12
.1
.08
.06
.04
.02
0

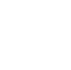

\footnotetext{
.
}

\begin{tabular}{|c|c|}
\hline $47^{\circ} \mathrm{N}$ & \\
\hline $46^{\circ} \mathrm{N}$ & .22 \\
\hline $45^{\circ} \mathrm{N}$ & .18 \\
\hline $44^{\circ} \mathrm{N}$ & .16 \\
\hline $43^{\circ} \mathrm{N}$ & .14 \\
\hline $42^{\circ} \mathrm{N}$ & .12 \\
\hline $41^{\circ} \mathrm{N}$ & .1 \\
\hline $40^{\circ} \mathrm{N}$ & .08 \\
\hline $39^{\circ} \mathrm{N}$ & .06 \\
\hline $38^{\circ} \mathrm{N}$ & .04 \\
\hline $37^{\circ} \mathrm{N}$ & .02 \\
\hline & 0 \\
\hline
\end{tabular}

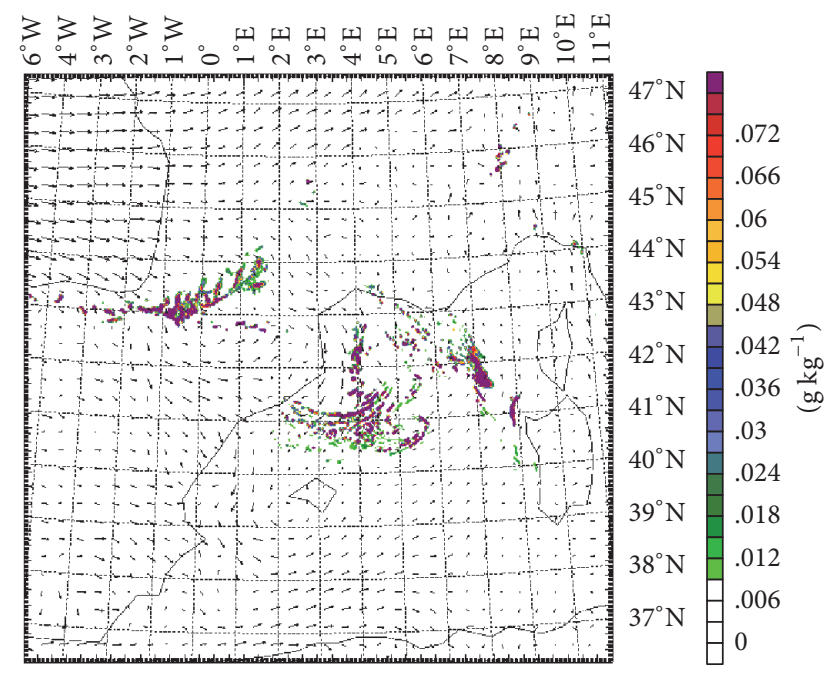

(b)

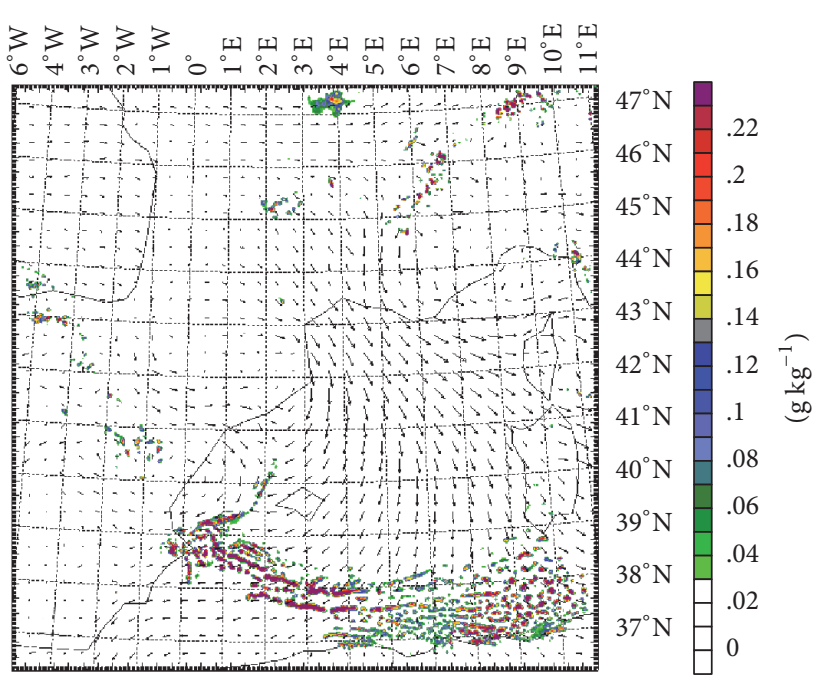

(d)

FIGURE 7: Simulated liquid water mixing-ratio at $700 \mathrm{~m}$ (color contours) and surface wind field (arrows) at (a) 08:00 UTC, (b) 10:00 UTC, and (c) 20:00 UTC on 25 August 2012 and (d) at 08:00 UTC on 26 August 2012. The maximum horizontal wind speed is, respectively, 12.4 $\mathrm{m} \mathrm{s}^{-1}$, $12.7 \mathrm{~m} \mathrm{~s}^{-1}, 17.5 \mathrm{~m} \mathrm{~s}^{-1}$, and $16.9 \mathrm{~m} \mathrm{~s}^{-1}$ in (a), (b), (c), and (d).

2011. A cold air mass moving down to the coastline is simulated during the night, forming a density current. This cold air mass, whose potential temperature ranges from 291 to $293 \mathrm{~K}$, moves offshore while the warmer Mediterranean air mass (potential temperature of around $296 \mathrm{~K}$ ) is lifted over the density current head at maximum vertical velocities of around $1 \mathrm{~m} \mathrm{~s}^{-1}$. Between 02:00 and 06:00 UTC (Figures 11(b)-11(d)), the offshore cold air mass depth ranges from 500 to $700 \mathrm{~m}$ of depth. The simulation shows a liquid cloud mixing-ratio over the density current head from around $800 \mathrm{~m}$ to over $2000 \mathrm{~m}$.

4.3. The Meso- $\gamma$ Scale Density Current on 11 October 2010. Figure 12 shows the simulated surface air convergence (color contours) and surface wind field (arrows) at (a) 22:00 and (b)
23:00 UTC on 13 October 2010 and (c) 00:00 UTC on 14 October 2010. At 22:00 UTC (Figure 12(a)), a convergence line is simulated, driven offshore by drainage winds (Figure 12(b)). The maximum length of around $40 \mathrm{~km}$ occurs at 00:00 UTC (Figure 12(c)). This line of convergence is simulated in the same location, and it presents the same duration of the recorded precipitation (see Figure 6). However, the model does not simulate any precipitation, probably due to the rapid offshore movement of the line of convergence, the short lifetime, and the small spatial scale in which the precipitation develops.

The depth of the cold air mass, $H$, has been estimated from the vertical cross section of the potential temperature along the line following the riverbed (not shown). At 00:00 UTC on 14 October 2010, the depth of cold reaches 300-400 m. 


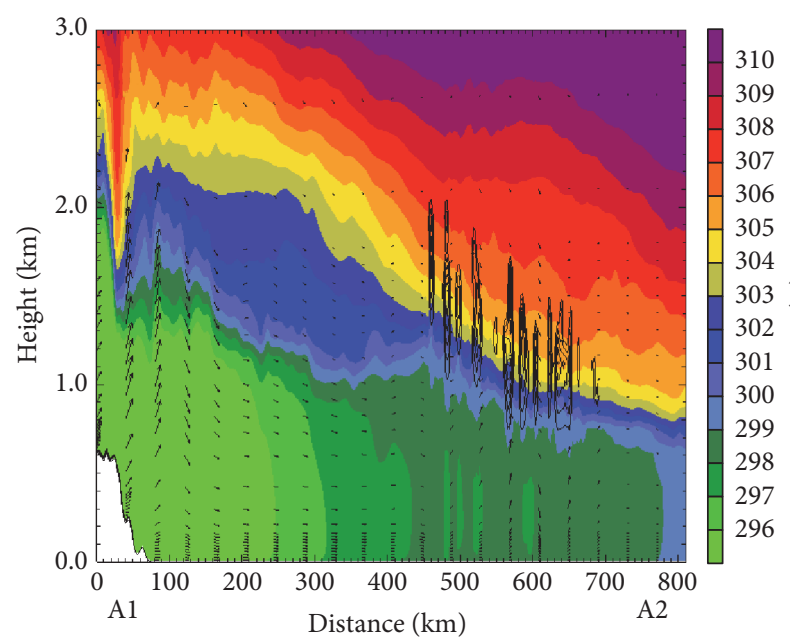

(a)

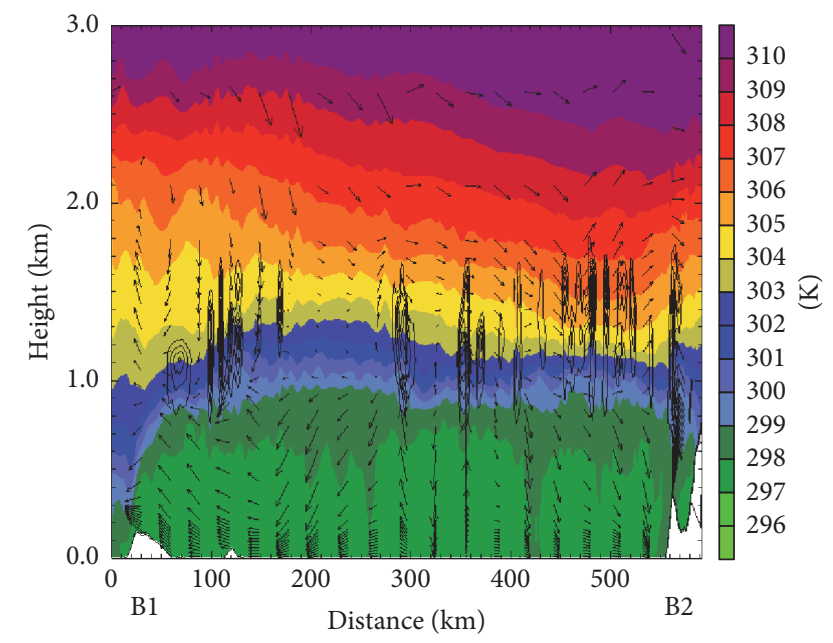

(b)

FIGURE 8: Vertical cross section of the simulated potential temperature (color contours), liquid water mixing-ratio (black contour lines, maximum value $0.18 \mathrm{~g} \mathrm{~kg}^{-1}$ ), and wind field (arrows) along the green lines (a) A1-A2 and (b) B1-B2 indicated in Figure 6(a) at 20:00 UTC on 25 August 2012. The maximum horizontal wind speed is $19.6 \mathrm{~m} \mathrm{~s}^{-1}$, and the maximum vertical wind vector is $25.6 \mathrm{~cm} \mathrm{~s}^{-1}$.

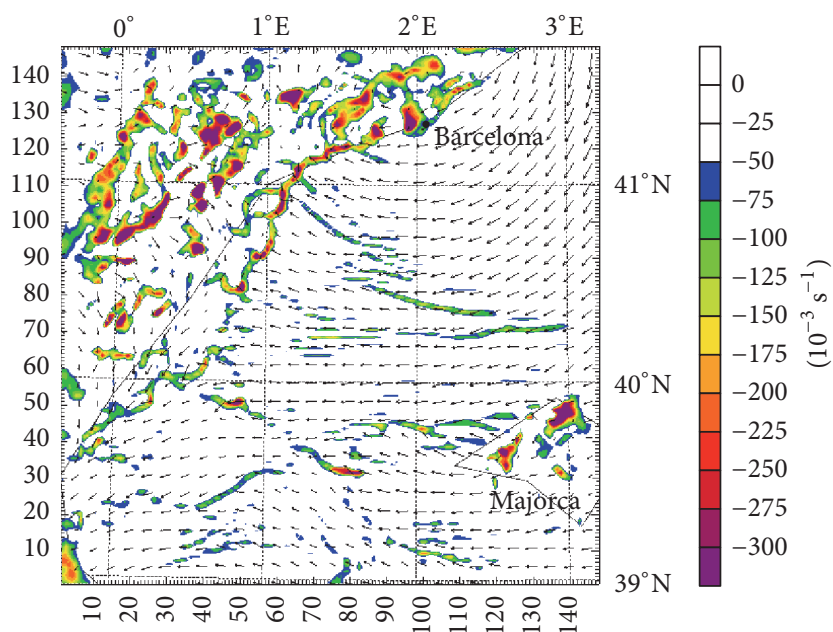

(a)

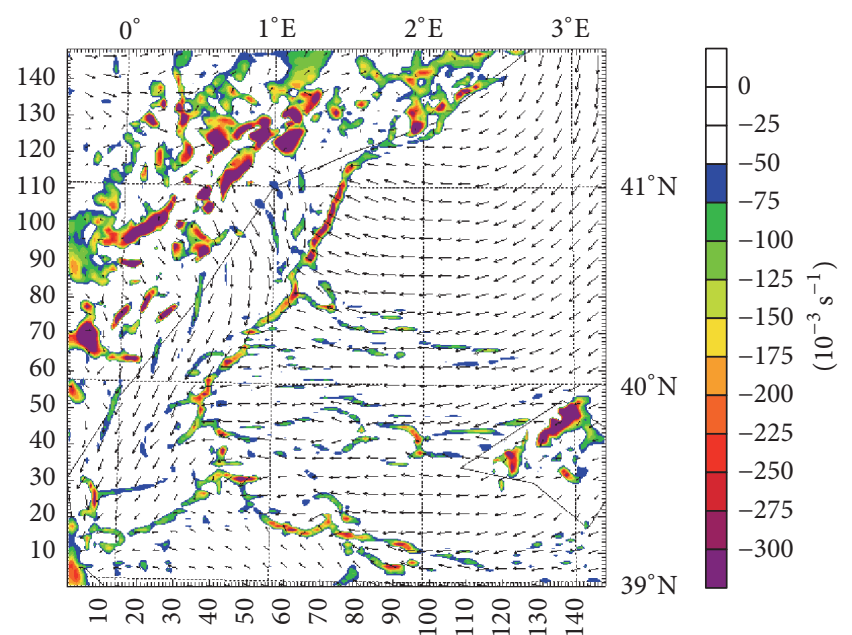

(b)

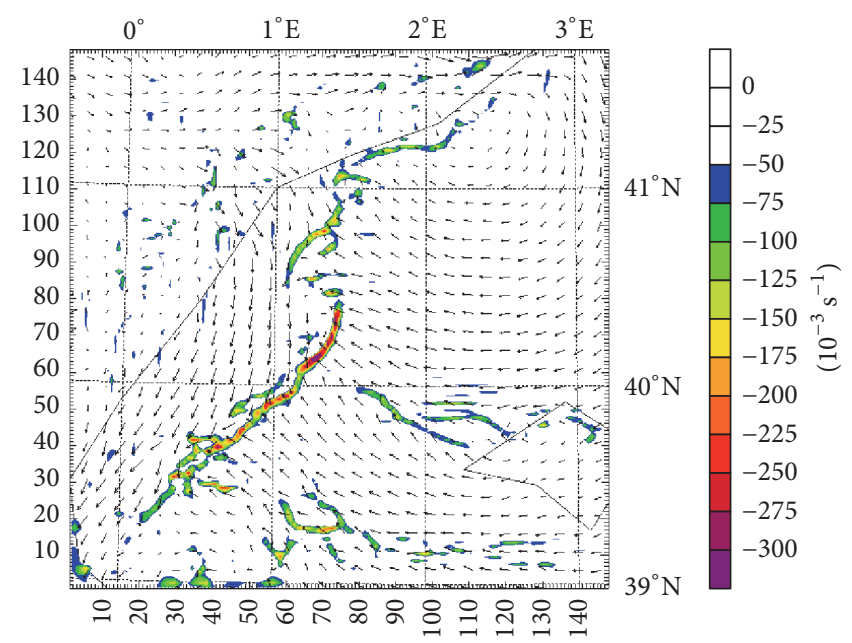

(c)

FIGURE 9: Simulated surface air convergence (color contours) and wind field (arrows) in the red domain of Figure 6(b) at (a) 00:00 UTC, (b) 03:00 UTC, and (c) 08:00 UTC on 6 September 2011. The maximum wind velocity is (a) $9.8 \mathrm{~m} \mathrm{~s}^{-1}$, (b) $9.7 \mathrm{~m} \mathrm{~s}^{-1}$, and (c) $8.6 \mathrm{~m} \mathrm{~s}^{-1}$. 


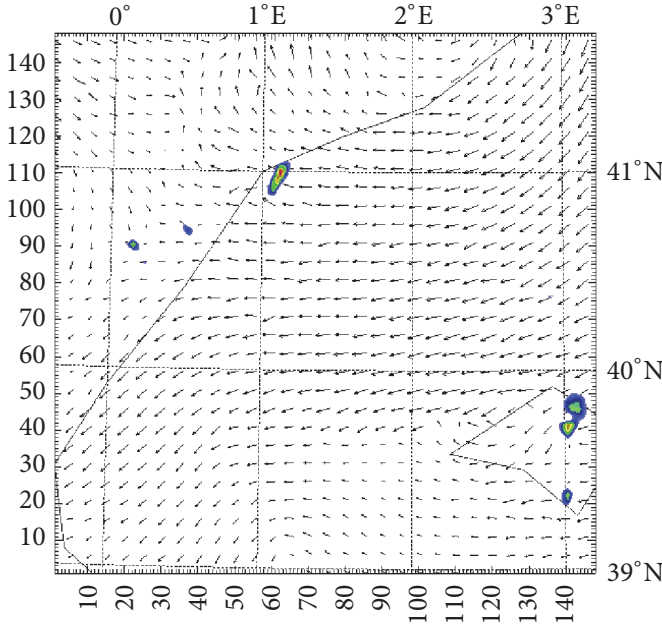

(a)

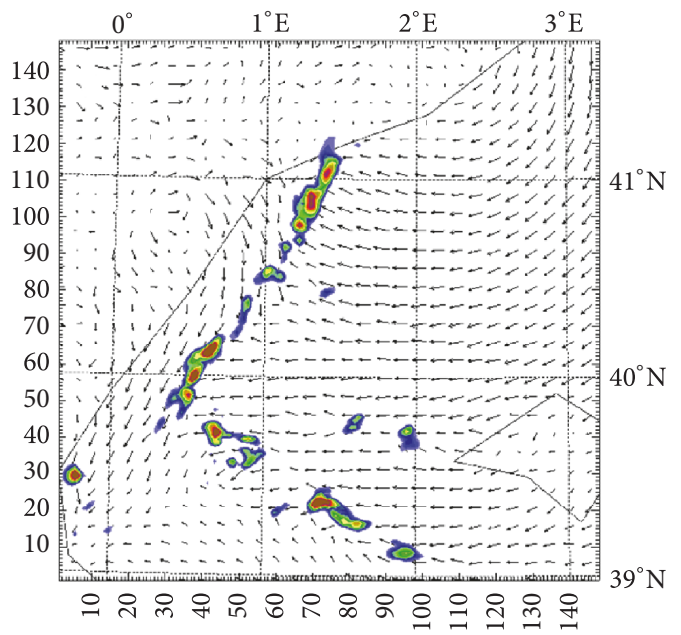

(c)

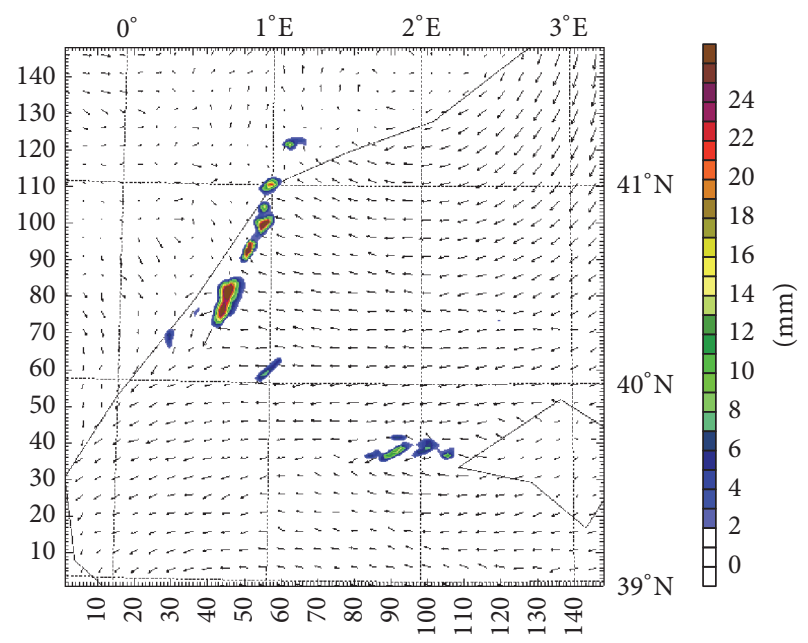

(b)

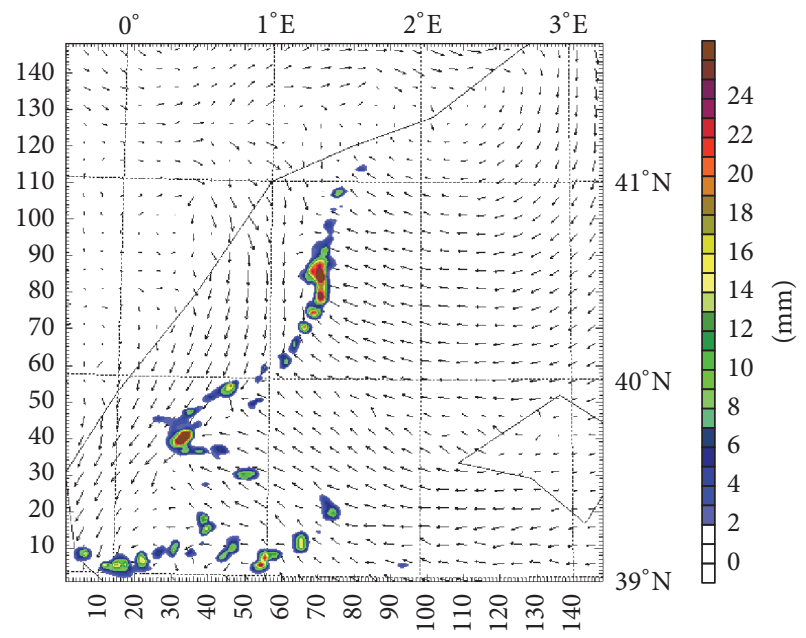

(d)

FIGURE 10: Simulated 1-h accumulated precipitation (color contours) and surface wind field (arrows) in the red domain of Figure 6(b) at (a) 22:00 UTC on 5 September 2011 and (b) 00:00 UTC and (c) 03:00 and (d) 08:00 UTC on 6 September 2011. The maximum wind speed is $10.6 \mathrm{~m} \mathrm{~s}^{-1}, 9.8 \mathrm{~m} \mathrm{~s}^{-1}, 9.7 \mathrm{~m} \mathrm{~s}^{-1}$, and $8.6 \mathrm{~m} \mathrm{~s}^{-1}$ in, respectively, (a), (b), (c), and (d).

TABLE 1: Simulation estimates of maximum characteristics of horizontal length $(L)$, vertical length $(H)$, and temporal $(T)$ scale, with calculated $H / L$ ratios [39] and corresponding mesoscales, according to Orlanski (1975).

\begin{tabular}{lccccc}
\hline Event & $L(\mathrm{~km})$ & $H(\mathrm{~km})$ & $H / L$ & $T(\mathrm{~h})$ & Scale \\
\hline 25 August 2012 & 2000 & $0.7-1$ & $10^{-4}$ & $24-30$ & Meso- $\alpha$ \\
6 September 2011 & 200 & 0.6 & $10^{-3}$ & $10-12$ & Meso- $\beta$ \\
13 October 2010 & 40 & $0.3-0.4$ & $10^{-2}$ & 3 & Meso- $\gamma$ \\
\hline
\end{tabular}

In order to classify and determine the scale of these three density currents, Table 1 summarizes the values obtained from the WRF simulation of the horizontal length $(L)$, vertical length $(H)$, and temporal $(T)$ scales, as well as the atmospheric scales in which they can be included.
Additionally, $H / L$ ratio defined by Markowski and Richardson [39] is also calculated in order to determine whether the cases are hydrostatic or nonhydrostatic. According to these authors, a meteorological phenomenon can be considered hydrostatic if $H / L \ll 1$.

\section{Conclusions}

Satellite and radar images of a WMB area were used to detect an offshore cloud band occurring in the meso- $\alpha$ scale and two events of rainbands occurring in the meso- $\beta$ and meso$\gamma$ scales. WRF simulations indicate that these clouds and rainbands are formed as a consequence of cold outbreaks which induce the formation of offshore density currents over the WMB at the three submesoscales.

The WRF simulation of the meso- $\alpha$ episode very effectively reproduces the observations recorded by the Meteosat satellite on 25 and 26 August 2012. This event is associated 


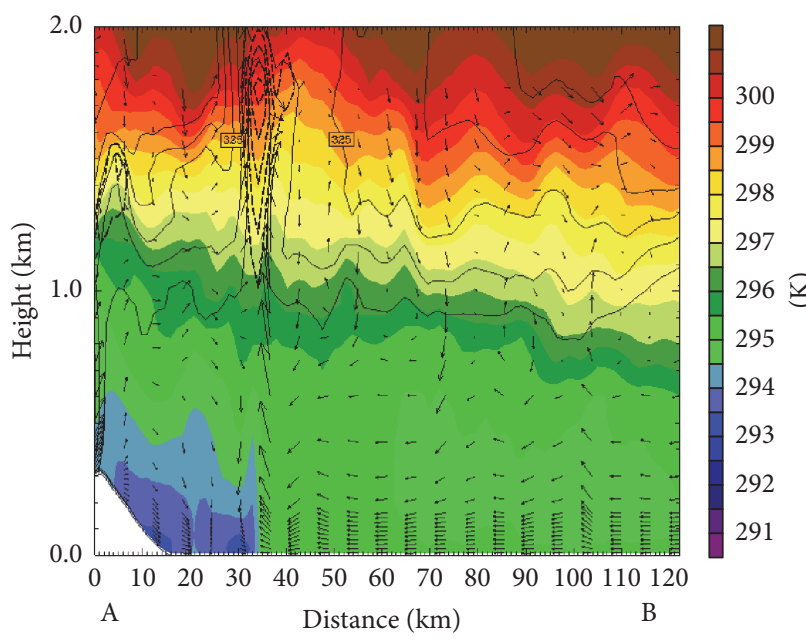

(a)

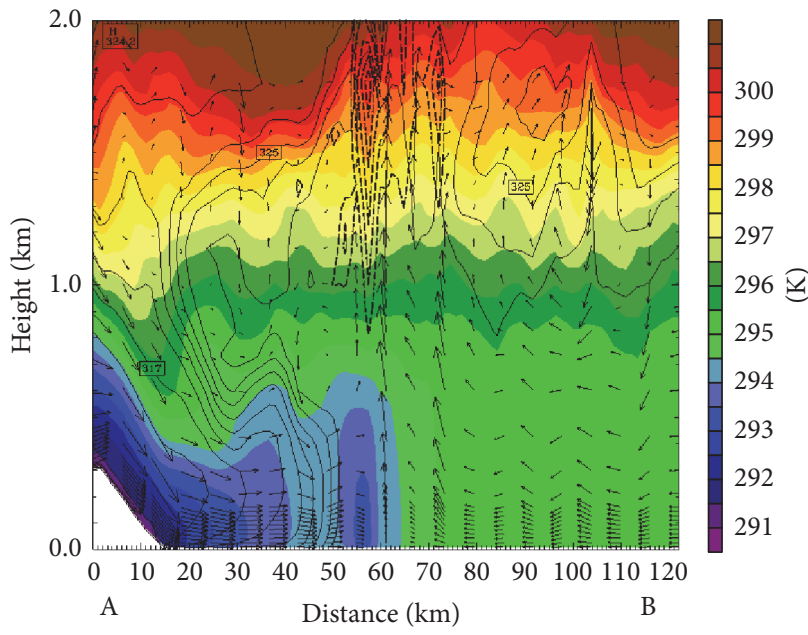

(c)

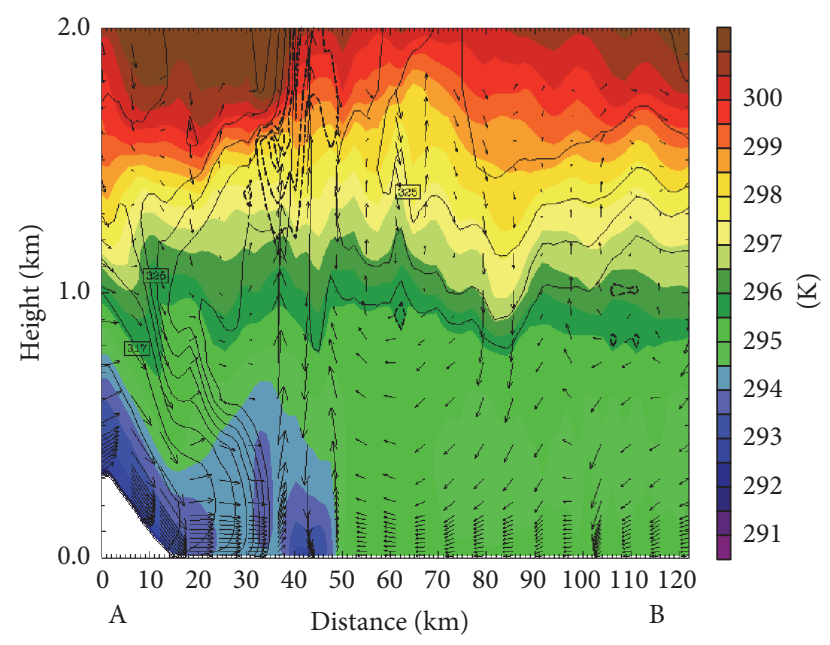

(b)

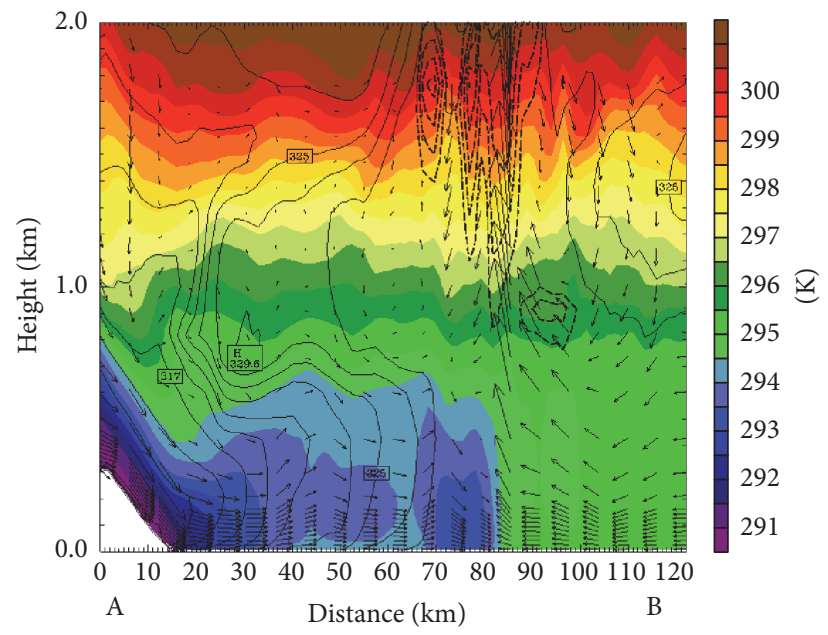

(d)

FIGURE 11: Vertical cross section of the simulated potential temperature (color contours), liquid water mixing-ratio (black contour lines, maximum value $5 \mathrm{~g} \mathrm{~kg}^{-1}$ ), and wind field (arrows) along line A-B shown in Figure 6(b) at (a) 00:00 UTC, (b) 02:00, (c) 04:00 UTC, and (d) 06:00 UTC on 6 September 2011. The maximum vertical wind speed is $1.2 \mathrm{~m} \mathrm{~s}^{-1}$.

with a strong Mistral event (northwesterly and northerly flow). Due to the channeling effect of the Pyrenees, the Alps, and the Massif Central, an outbreak of cold air is produced and it expands offshore into the Gulf of Lion, where it enters the $\mathrm{WMB}$ and interacts with a warmer sea air mass over the Mediterranean Sea.

During the night and early morning of 5-6 September 2011, a line of precipitation was detected by the radar network of the Spanish Meteorological Agency and also simulated by the WRF model. The simulation shows that this line of precipitation was associated with a density current formed by the interaction between a cold air mass arriving at the sea as a result of a drainage wind and a warmer prevailing synoptic flow.

The radar network of the Catalan Weather Service recorded a single, small precipitation cell a few kilometers offshore in the northeast of the Iberian Peninsula on 11 October 2010. According to the WRF simulation, a density current formed as a result of the prevailing wind interacting with the drainage winds following two riverbeds.

From the observations and simulations of these three episodes, it might be suggested that this relatively small area within the WMB can be considered a region where density currents forming at the mesoscale are associated with outbreaks of cold air that occur over the relatively warm sea air at the whole mesoscale. However, three episodes of density currents entering this region are not enough for considering that this region is an area where these phenomena occur at the whole mesoscale. Further episodes should be found and studied to ensure any conclusions of this nature. This paper aims to point out the evidence found through these three cases of cold outbreaks at the whole mesoscale and to encourage more research on this topic as it relates to this area. 


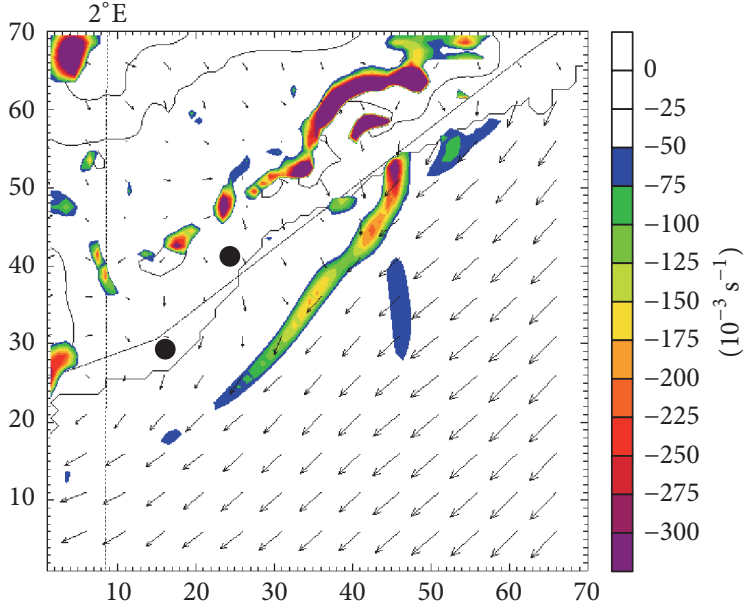

(a)

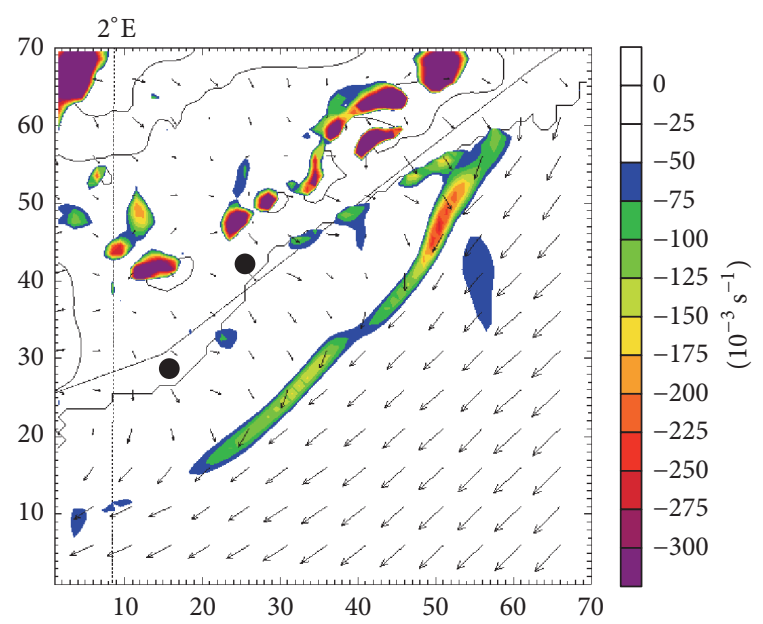

(b)

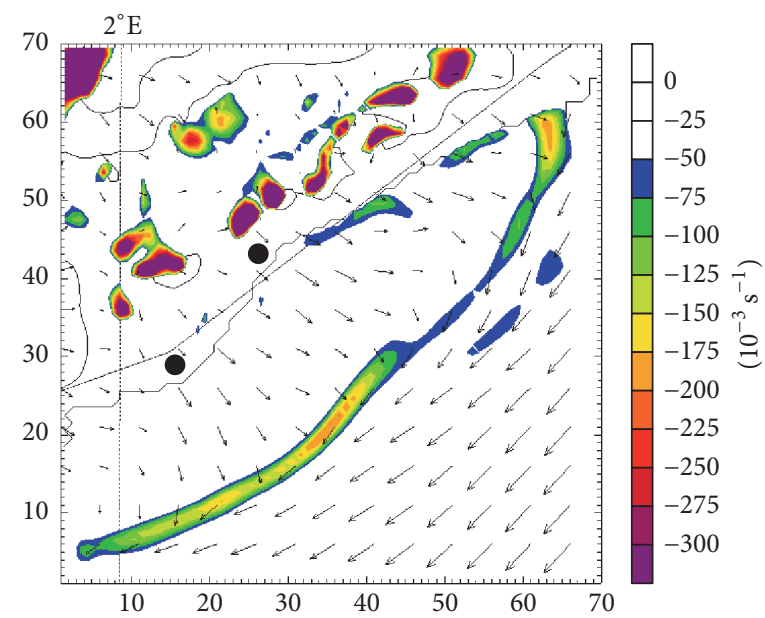

(c)

FIGURE 12: Simulated surface air convergence (color contours) and surface wind field (arrows) in domain d04 of Figure 6(c) at (a) 22:00 and (b) 23:00 on 13 October 2010 and (c) 00:00 UTC on 10 October 2010. The maximum wind speed is (a) $4.6 \mathrm{~m} \mathrm{~s}^{-1},(\mathrm{~b}) 5.2 \mathrm{~m} \mathrm{~s}^{-1}$, and (c) $5.1 \mathrm{~m} \mathrm{~s}^{-1}$.

\section{Conflicts of Interest}

The authors declare that there are no conflicts of interest regarding the publication of this paper.

\section{Acknowledgments}

The WRF simulations were performed by using the resources of the Supercomputing Center of Catalonia (CSUC). The authors were partially financed by the Spanish MINECO projects CGL2009-08609 and CGL201237416-C04-03. The authors are also grateful to the Spanish Weather Agency (AEMET) and the Catalan Meteorological Service (MeteoCat) for the use of their images and to Eumetsat for the Meteosat images.

\section{References}

[1] V. E. Kousky, "Diurnal rainfall variation in Northeast Brazil," Monthly Weather Review, vol. 108, no. 4, pp. 488-498, 1980.
[2] J. L. Frye and Y.-L. Chen, "Evolution of downslope flow under strong opposing trade winds and frequent trade-wind rainshowers over the island of Hawaii," Monthly Weather Review, vol. 129, no. 5, pp. 956-977, 2001.

[3] T. Ohsawa, H. Ueda, T. Hayashi, A. Watanabe, and J. Matsumoto, "Diurnal variations of convective activity and rainfall in tropical Asia," Journal of the Meteorological Society of Japan, vol. 79, no. 1, pp. 333-352, 2001.

[4] B. E. Mapes, T. T. Warner, M. Xu, and A. J. Negri, "Diurnal patterns of rainfall in northwestern South America. Part I: observations and context," Monthly Weather Review, vol. 131, no. 5, pp. 799-812, 2003.

[5] J. Li and Y.-L. Chen, "A case study of nocturnal rain showers over the windward coastal region of the island of Hawaii," Monthly Weather Review, vol. 127, no. 11, pp. 2674-2692, 1999.

[6] P. Wu, M. D. Yamanaka, and J. Matsumoto, "The formation of nocturnal rainfall offshore from convection over Western kalimantan (Borneo) Island," Journal of the Meteorological Society of Japan, vol. 86, pp. 187-203, 2008.

[7] T. Glickman, Glossary of Meteorology, American Meteorology Society, Boston, Mass, USA, 2nd edition, 2000. 
[8] L. M. Schoenberger, "Doppler radar observations of a landbreeze cold front," Monthly Weather Review, vol. 112, no. 12, pp. 2455-2464, 1984.

[9] J. Neumann, "Land breezes and nocturnal thunderstorms," Journal of Meteorology, vol. 8, pp. 60-67, 1951.

[10] J. H. Meyer, "Radar observations of land breeze fronts," Journal of Applied Meteorology, vol. 10, no. 6, pp. 1224-1232, 1971.

[11] T. B. Benjamin, "Gravity currents and related phenomena," Journal of Fluid Mechanics, vol. 31, no. 2, pp. 209-248, 1968.

[12] T. von Kármán, “The engineer grapples with non-linear problems," Bulletin of the American Mathematical Society, vol. 46, pp. 615-683, 1940.

[13] L. Prandtl, Essentials of Fluids Dynamics, Hafner, New York, NY, USA, 1952.

[14] G. H. Keulegan, Twelfth Progress Report on Model Laws for Density Currents: The Motion of Saline Fronts in Still Water, vol. 5831, US Dept. of Commerce, National Bureau of Standards, 1958.

[15] R. Clarke, "Mesostructure of dry cold fronts over featureless terrain," Journal of Meteorology, vol. 18, article 715, 1961.

[16] J. E. Simpson and R. E. Britter, "A laboratory model of an atmospheric mesofront," Quarterly Journal of the Royal Meteorological Society, vol. 106, no. 449, pp. 485-500, 1980.

[17] R. H. Heiblum, I. Koren, and O. Altaratz, "Coastal precipitation formation and discharge based on TRMM observations," Atmospheric Chemistry and Physics, vol. 11, no. 13, pp. 201-217, 2011.

[18] D. Malda, J. V.-G. De Arellano, W. D. Van Den Berg, and I. W. Zuurendonk, "The role of atmospheric boundary layer-surface interactions on the development of coastal fronts," Annales Geophysicae, vol. 25, no. 2, pp. 341-360, 2007.

[19] M. M. Miglietta and R. Rotunno, "Numerical simulations of low-CAPE flows over a mountain ridge," Journal of the Atmospheric Sciences, vol. 67, no. 7, pp. 2391-2401, 2010.

[20] Y. Goldreich, H. Mozes, and D. Rosenfeld, "Radar analysis of cloud systems and their rainfall yield in Israel," Israel Journal of Earth Sciences, vol. 53, no. 2, pp. 63-76, 2004.

[21] A. Callado and R. Pascual, "Storms in front of the mouth rivers in north-eastern coast of Iberian Peninsula," in Proceedings of the 4th Plinius Conference on Mediterranean Storms, Mallorca, Spain, 2002.

[22] J. M. Jansa, "La masa de aire mediterraneo," Revista de Geofísica, vol. 18, pp. 35-50, 1959.

[23] I. Orlanski, "A rational subdivision of scales for atmospheric processes," Bulletin of the American Meteorological Society, vol. 56, pp. 527-530, 1975.

[24] C. Flamant, "Alpine lee cyclogenesis influence on air-sea heat exchanges and marine atmospheric boundary layer thermodynamics over the western Mediterranean during a Tramontane/Mistral event," Journal of Geophysical Research, vol. 108, no. 2, pp. 5-24, 2003.

[25] C. Millot, "Wind induced upwellings in the Gulf of Lions," Oceanologica Acta, vol. 2, pp. 261-274, 1979.

[26] Q. Jiang, R. B. Smith, and J. Doyle, "The nature of the mistral: observations and modelling of two MAP events," Quarterly Journal of the Royal Meteorological Society, vol. 129, no. 588, pp. 857-875, 2003.

[27] A. Jansá, "Distribution of the mistral: a satellite observation," Meteorology and Atmospheric Physics, vol. 36, no. 1-4, pp. 201214, 1987.
[28] I. F. Trigo, T. D. Davies, and G. R. Bigg, "Objective climatology of cyclones in the Mediterranean region," Journal of Climate, vol. 12, no. 6, pp. 1685-1696, 1999.

[29] J. Campins, A. Genovés, A. Jansà, J. A. Guijarro, and C. Ramis, "A catalogue and a classification of surface cyclones for the Western Mediterranean," International Journal of Climatology, vol. 20, no. 9, pp. 969-984, 2000.

[30] J. Mazon and D. Pino, "Nocturnal offshore precipitation near the Mediterranean coast of the Iberian Peninsula," Meteorology and Atmospheric Physics, vol. 120, no. 1-2, pp. 11-28, 2013.

[31] J. Mazón and D. Pino, "The role of sea-land air thermal difference, shape of the coastline and sea surface temperature in the nocturnal offshore convection," Tellus, vol. 65, Article ID 20027, 2013.

[32] J. Mazon and D. Pino, "Role of the nocturnal coastal-front depth on cloud formation and precipitation in the Mediterranean basin," Atmospheric Research, vol. 153, pp. 145-154, 2015.

[33] J. Mazon, Nocturnal coastal fronts in the Mediterranean basin [Ph.D. thesis], 2015.

[34] W. C. Skamarock, J. B. Klemp, J. Dudhia et al., "A description of the advanced research wrf version 3," Tech. Rep. TN-475+STR, NCAR, Boulder, Colo, USA, 2008.

[35] S.-Y. Hong and H.-L. Pan, "Nonlocal boundary layer vertical diffusion in a medium-range forecast model," Monthly Weather Review, vol. 124, no. 10, pp. 2322-2339, 1996.

[36] E. J. Mlawer, S. L. Taubman, P. D. Brown, M. J. Iacono, and S. A. Clough, "Radiative transfer for inhomogeneous atmospheres: RRTM, a validated correlated-k model for the longwave," Journal of Geophysical Research, vol. 102, pp. 663-682, 1997.

[37] J. Dudhia, "Numerical study of convection observed during the Winter Monsoon Experiment using a mesoscale twodimensional model," Journal of the Atmospheric Sciences, vol. 46, no. 20, pp. 3077-3107, 1989.

[38] S-Y. Hong and J. O. J. Lim, "The WRF single-moment 6-class microphysical scheme (WSM6)," Journal of Korean Meteorological Society, vol. 42, no. 2, pp. 129-151, 2006.

[39] P. Markowski and Y. Richardson, Mesoscale Meteorology in Midlatitudes, Wiley, Chichester, UK, 2010. 

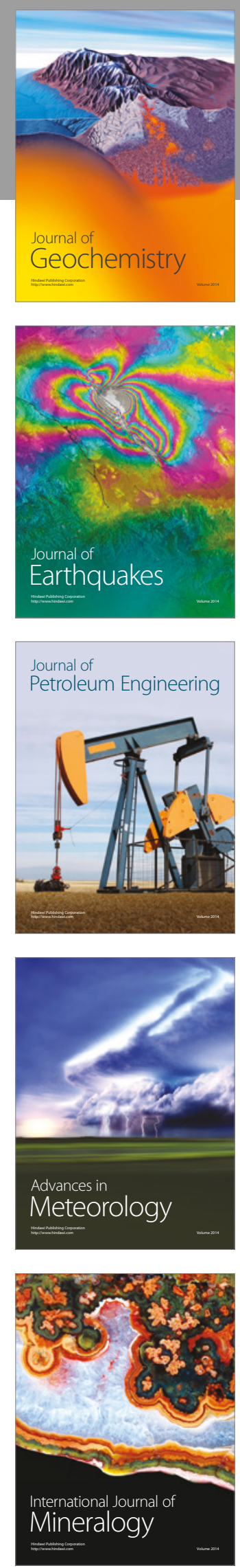
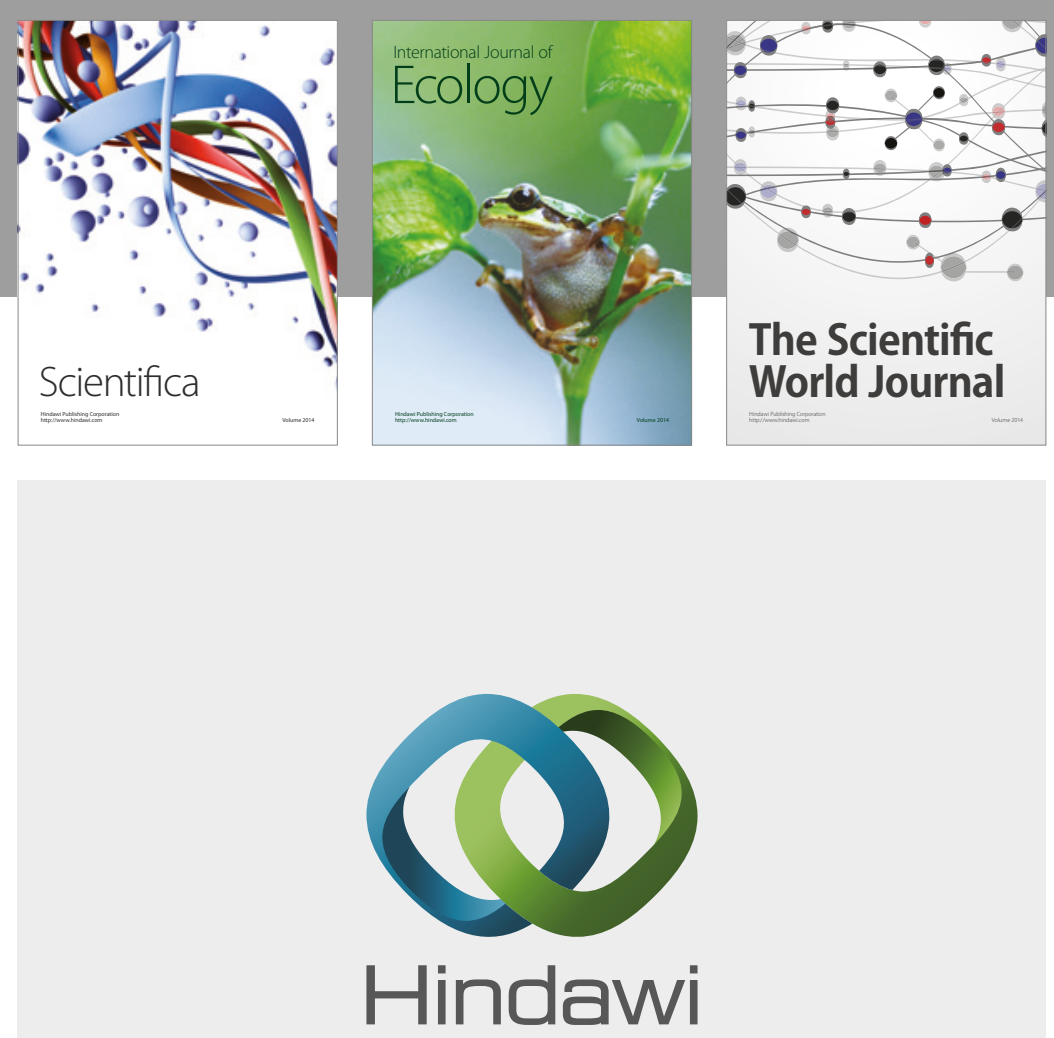

Submit your manuscripts at

https://www.hindawi.com
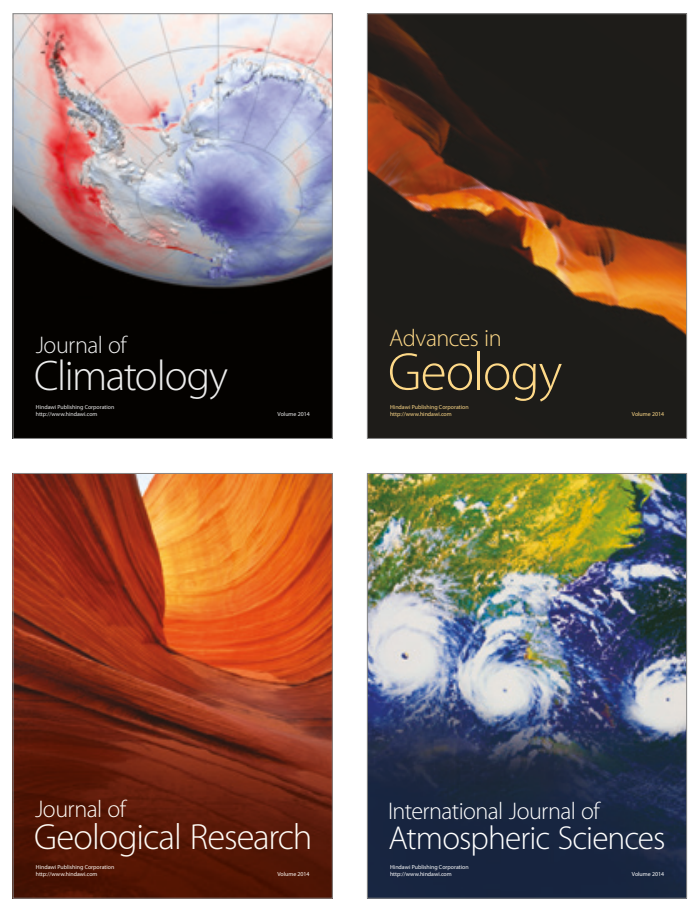

The Scientific

World Journal
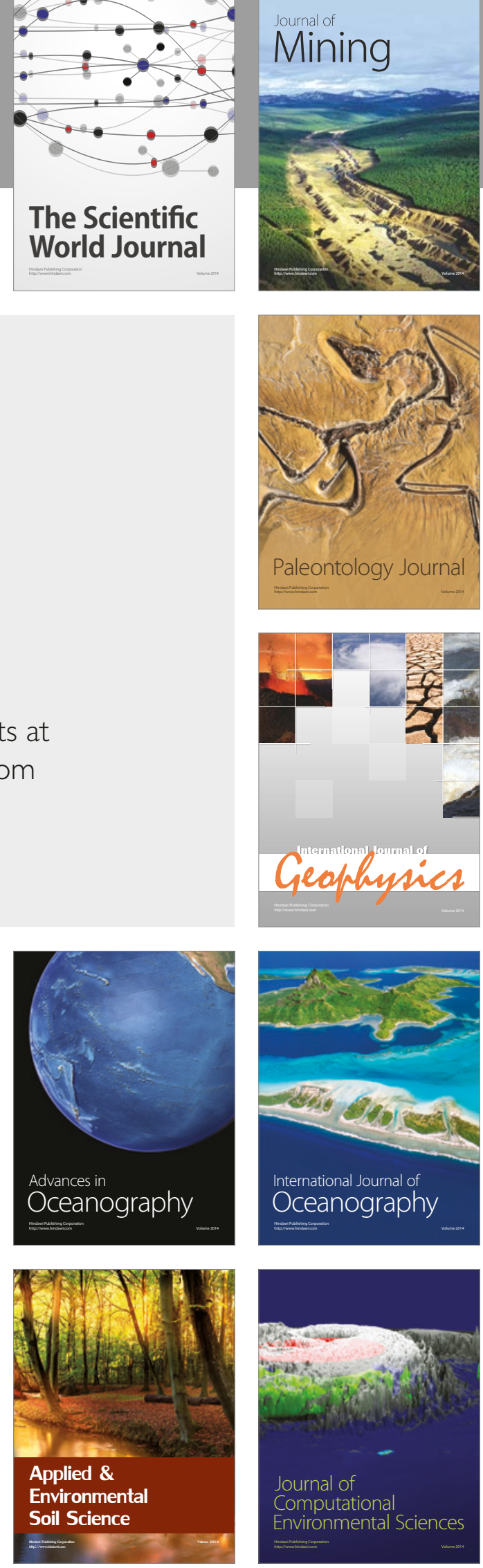